\title{
Strategies to Make Polite Communication in Balinese
}

\author{
I Nyoman Kardana ${ }^{1}$ and Made Sri Satyawati ${ }^{2}$ \\ \{ikardana@yahoo.com¹ and srisatyawati@gmail.com² ${ }^{2}$. \\ Universitas Warmadewa, Denpasar, Bali-Indonesia ${ }^{1}$ and Universitas Udayana, Denpasar, Bali-Indonesia ${ }^{2}$
}

\begin{abstract}
The development of tourism in Bali has contributed many positive impacts on the economy of the local community. The availability of professional human resources who have good foreign language skills has become very important in tourism development. This has led the increase of the interest of young generation to master foreign languages. Unfortunately, this condition has made their interest in mastering the local language has declined so that nowadays many young Balinese people have problem to use their Balinese in their daily communication. Meanwhile, Bali has a system of caste level which needs the language courtesy. For the reason, this study is very important to be conducted to examine how Balinese system realizes polite communication. From the collected data it was found that the speakers who can't master Balinese still have a chance to make polite communication when a situation has to force them to speak polite Balinese.
\end{abstract}

Keywords: Deixis; indirect speech act; lexicon tourism

\section{Introduction}

Nowadays many young people in Bali have a problem to communicate each other in polite Balinese. This is one of the impacts of tourism development in Bali that is well known as the center of tourism development and the most popular destination in Indonesia. The tourism sector certainly requires professional human resources who master foreign languages as a means of international communication. This cause the young generation in Bali prefers learning and mastering foreign languages to Balinese. They think that if they master foreign languages they will easily find jobs in Bali and beyond and even abroad and it will make their families' economy better. However, this condition could make the use of Balinese, especially by young generation, decline.

Balinese is one of local languages in Indonesia that has language level. If the speakers can understand and use the all level of Balinese, they do not have any problem to use Balinese in any situation they have and they are not worried to speak polite Balinese to particular person they have to respect. However, tourism development in Bali has changed many things including the interest of the young people in mastering Balinese as their own local language. The decline of the interest of young people to learn and use Balinese can affect the lives of Balinese people. This is due to the difficulties faced by the young generation to communicate in Balinese. Meanwhile, community in Bali which has a caste system and level of social status requires people to pay attention to polite communication. In addition, Balinese has uniqueness related to its structure and its function in the social-cultural life of the speakers [1]. For this reason, settlements to be able to communicate Balinese politely are very necessary to figure out, especially for those who cannot master Balinese well. In relation to this phenomenon, this study aims to examine how speakers of Balinese can produce polite communication to create 
harmonious relationships between the speakers. Thus, polite communication is very important to discuss if the speakers can't use language in accordance with the situation, or if they make a mistake in using a language it will be able to create linguistic conflict that results in a social conflict as conveyed by Kusno [2]. The use of polite language is not only used in general community but also institutional organization that shows the importance of polite language in our society [3]. The use of polite language is not separated from the speakers both male and female. The use of language through different gender shows similarities and differences based on the users perception [4]. Teaching about polite language could be a way to keep the existance of the language. Senowarsito explores the politeness strategies used by the teacher and students. The use of polite language by a teacher could make the polite language understandable by the students [5]. Polite language is not only presented by the speakers through utterances but also through writing [6]. It means that polite language still exists in the society as a part of cultures. Every language has their own way to express politeness, such as styles of politeness and sign expressions [7]. That is why polite language should be maintained in order to exist as our local culture. In addition, there are some efforts that can be done to maintain and develop the local language, such as: the use of languages in families, society, communities, mass media, etc. [8].

Data of this research was taken from Balinese speakers living in Denpasar city. The informants are decided and selected based on sampling system without any special consideration. Observation method was applied in order to collect data. The collected data deals with the use of Balinese in polite communication. Interview method to the informants was applied as well to know whether the utterances spoken by speakers were considered polite or impolite by hearers. The collected data was then classified based on the strategies applied by the speakers to make polite communication in Balinese. The results are presented descriptively in the part of discussion. It means that a descriptive method is applied in order to make a systematic and accurate description on the data, characteristics, and phenomenon in relation to the collected data [9].

\section{Discussion}

Balinese a language of three levels: i.e. standard (middle), and high level. The difference among those levels comes to their lexicons but their structure seems similar. Balinese people who can understand and use the three levels of Balinese will not have any problems to use Balinese in any situation. If a situation forces them to create polite communication they can use the high level of Balinese to result in perfect polite Balinese. A big problem happens to those who can't understand and use the high level of Balinese or for those who only know a few words of Balinese. Based on the analysis to the collected data, it was found that there is a way to solve this problem. The way to create polite communication in Balinese can be distinguished into three different strategies: (1) using indirect speech, (2) using particular deixis, and (3) using particular lexicons. The ways to make polite communication in Balinese are described in the following discussion. Each discussion is supported by some examples.

\subsection{The Use of Indirect Speech Act}

Indirect speech is a kind of utterance that is expressed with a type of sentence that is not in accordance with the purpose of the speech, but the meaning of the words that compose it is in accordance with what the speakers intend [10]. This type of speech is often used in Balinese 
with the intention to make the speech more polite. Some examples are presented in the following discussion.

\section{The Use of Declarative Sentence.}

Declarative sentence aims to convey news or information. However, declarative sentences can be also used for other purposes, such as the purpose of governing, inviting, and asking or begging. The use of declarative sentence for such purposes and not for conveying information is called indirect speech in which the speaker conveys the intention of request or command not with an imperative sentence, but with a declarative sentence. The speakers of Balinese often use the declarative sentence when they want to make request and command in polite communication. It can be proved by the following examples.

1) S: Di sanggah luu-ne liu gati, Mbo Kadek.

In the temple there is a lot of garbage, sister Kadek'

$\mathrm{H}$ : Bin jebos Mbo kadek lakar nyampat

I will sweep it soon'

2) S: Bu, Ibu durung mayah canang.

Madam, you have not paid the offering yet'

$\mathrm{H}$ : Nah, jani ibu mayah.

Okay, I pay it now

In the context of a girl talking to a servant who lives in her house in data (1) and a servant talking to a woman (her host) in data (2), it is known that the declarative speeches in both examples do not only contain information, but they tend to have meaning as an instruction to the hearer (the servant) to sweep the area of the temple in (1) and to the woman (the host) to pay the offering in (2). In this case, the hearers understand that the meaning of the speeches is a command and not just an information. The hearers can directly understand the command although the speeches are in declarative sentence. The speakers are very concerned about manners to govern someone, even to a servant. The hearers can also quickly understand the speaker's intention that the declarative sentence in (2) above means an order rather than an information. From the examples it is known that the speaker (a girl) used standard Balinese to her servant and she preferred using indirect speech act to direct one as she wanted to keep a good communication to her servant. Different situation happened to the example (2), the speaker (servant) should use high level Balinese to communicate to her host, but because she could not master and use high level Balinese, she used standard indirect speech with one high level word to show her respect to her host. The utterance spoken by the speaker could be considered as a polite command by the hearer (host).

Besides as command, declarative sentence can be used for invitation as well. The use of declarative sentence for the purpose of command can be seen in the following examples.

1) S: Bu, bin mani ada pementasan tari uling Bangli di Taman Budaya. Mom, tomorrow there will be a dance performance from Bangli at Art Center'

$\mathrm{H}$ : Ayo mabalih yuk. Okay let's watch it'.

Declarrative sentence in the example above is spoken by a man to his wife. He wanted to invite his wife to watch a dance performance that will be conducted at art center. The man used declarative sentence in order to make polite invitation to his wife and not just to give information. The invitation expressed in ordinary language was understood to contain polite meaning because of the indirect speech.

\section{The Use of Interrogative Sentence}


Interrogative sentence is generally used to ask something. However, the reality in Balinese use, interrogative sentence is also often used for other purposes. Interrogative sentence can be used for commands, invitations, and requests [11]. This is also one of the strategies used by Balinese speaker to create polite communication. The use of interrogative sentence for such purposes is commonly used by speakers who can't master and understand high level Balinese but in another side they want to make polite utterance to have harmonious communication. The use of interrogative for command and invitation can be seen in the following data:

1) S: Suba kayehang adike dek?

Did you bathe the baby Dek?

$\mathrm{H}$ : Nggih, mangkin sampun

Okay, I will do it now

2) S: Sing makita malali ke pameran Bu?

Don't you intend to visit the festival Mom?

H: Lan jam pitu nah Pak.

Okay, we go there at seven

The interrogative sentences above explain that in addition to have questioning meaning, they both also contain the meaning of command or request like in (1) and invitation like in (2). The meaning of the indirect command or request and invitation more dominates the meaning of the sentences. The response of the hearers in the examples above proves that the interrogative sentences spoken by the speakers are directly understood as a command and invitation and not just a question. The purpose of the indirect invitation from the interrogative sentence is still related to the literal meaning of the question-forming elements so that the indirect invitation in (2) is called a literal indirect invitation [12]. Further more Leech stated that the other way to recognize the politeness scale is by looking at the content of the same utterances by using various indirect speech acts [13]. What is discussed above is in accordance with what is said by Lindayana, et.al [14] who stated that speaking activity is very necessary to assume the principle of courtesy. Language politeness can be seen in the process of directive speech acts done in the learning process. This is realized through the act of asking, commanding, advising, and inviting.

From the examples it could be understood that the speakers of Balinese like using indirect speech rather than direct one. For instance, in (1), when a lady ordered her servant to bathe her baby she used indirect speech command and not direct command in imperative sentence. The example (2) shows the same when a man invited his wife to visit festival he preferred using indirect speech than direct one. When they used standard Balinese for their communication they choose to use indirect speech in order to keep harmonious communication.

\subsection{The Use of Particular Person Deixis and Social Deixis.}

Balinese people will not have any problem with polite communication if they master and can use all level of Balinese. They will have perfect polite communication with high level Balinese in order to express something politely. However, the reality shows that not all Balinese speakers understand and are able to master Balinese very well. For their daily communication, either in the family, formal or informal situation, and many speakers of Balinese use ordinary or standard Balinese. If they are obliged to speak politely because of certain situation, for instance when they are communicating with older people or with someone who has higher socio-economic and socio-cultural status, those who are lack in Balinese, such as young generation living in the urban area, they still have other strategy to create polite communication. They usually use certain person and social deixis to express 
politeness. For discussion of deixis in Balinese, understanding of deixis stated by Saeed [11] is used as the basis of reference.

1) S: Titiang nike ngelah Jero De.

It belongs to me Jero De

H: Oh nggih silih nah.

Okay, let me borrow

2) S: Ipun ane sanggup mragatang gaene Jero Kelih.

He promised to finish the work

H: Nggih suksma, enggal nah.

Okay thank you, finish it soon

The two examples used standard language and the utterances are considered polite due to the presence of person deixis of high level pronouns which refer to the first person singular titiang in (1) and third person singular ipun in (2). The presence of these polite level pronouns is able to make the whole speech contain the impression of being polite and quite refined. In Balinese the form titiang can refer to first singular and plural pronoun. It is different from other local languages in Indonesia. In using language for example, it has two different forms for first pronoun: isun for singular and isun-rika for plural pronoun [15].

Since in Bali there is a caste level and socio-cultural status, Baline language has many forms of social deixis. Social deixis has a big and important role in Balinese communication. Standard Balinese may have polite impression as well if the speech contains social deixis reffering to the person respected by the speakers. Look at the following examples.

1) S: Tu Aji, dija polih siap biing?

Mr. Aji, where did you get the red cock?

H: Di Bangli Ngah

In Bangli Ngah

2) S: Jero Mangku, bin pidan lakar ngayah di pura?

Mr. Mangku, when shall we prepare things at the temple?

H: Uling bin puan Men Tu

It's from the day after tomorrow, Madam Putu.

The forms of social deixis Tu Aji (call name for high level married man from Brahmana) and Jero mangku (call name for those who dedicate themselves at a temple) cause the standard speech containing those social deixis to be polite and subtle. It means that although the utterances used standard language, if any social deixis are inserted into the utterances, they can be considered polite and can be acceptable utterance for any situation. The hearers in the context above will not have any problems with the utterances spoken by speakers and they think they have been appreciated by the speakers with the use of the social deixis in their utterances. The utterance will be more polite if a high level word as polih 'to get' could be inserted to the utterance as in (3).

\subsection{The use of Particular Lexicon}

In addition to the above strategies, there is another method to make polite Balinese communication especially for those who can't speak Balinese well. They usually often insert one or more certain lexicons of Balinese in their standard language to make polite communication. This can be seen in the following examples.
1) Tiang wawu neked jumah niki
I have just arrived home'
2) Sire mai busan me?
Who has just come here mom? 
Pagaenne I Bagong mulan becik, pantes maan juara.

Bagong's work is definitely good; he is worth being the winner.

The three examples above are standard speeches that contain certain high level Balinese lexicons. The use of the lexicons causes the standard speeches to be polite or considered to be polite by the hearers. In speech (1) there is a polite (high level) adverb wawu 'just now'. In the speech (2) there is a form of high level question word sire 'who' which causes the speech to be polite. In the speech (3) there is an adjective becik 'good' that belongs to high level language. Thus, the lexicons used to make polite speech in standard or ordinary speech can be in the form of adverb, question word, and adjective. Verb or verb phrase is also possible inserted in standard language to make the utterance polite. The examples can be seen below.

1) Bapanne anak ten maduwe pis anggona mayah.

His father did not have any money to pay'

2) Asananga kurenan tiange sampun uning, Ratu.

Perhaps my husband has already known that, ratu'

3) Adin tiange nikaang mai melali, Jero Tut.

My younger sister/brother said that she/he is going to come here, Jero Tut'

Standard Balinese utterances in (4) and (5) contain verb phrase of high level language ten maduwe 'not to have' and sampun uning 'have known'. The high level verb phrases made the utterances become polite and they could be acceptable utterance spoken by those who have problem to make polite communication in Balinese. The presence of single high level verb nikaang 'to say' in example (6) has also made the standard utterance polite. Based on the information collected from young informants they often used this strategy in order to cover their problem in making polite communication in Balinese.

Insertion of particular Balinese deixis and lexicons to Indonesian utterances also often happens on communication by young people. This strategy has much helped Balinese young people to solve their problem to speak Balinese. The use of particular deixis and lexicons has shown their respect to special people they are talking to, based on socio-economic status or socio-cultural status. For those who only know a few Balinese words, this strategy has helped them make a good communication. This is the easiest way often found in young people's communication. Look at the following examples.

1) Kek, ampure tiang tidak bisa bicara bahasa Bali.

Grandfather, I am sorry not to be able to speak Balinese'

2) Kemarin dia sampun ke sini tapi mangkin dia minta ijin.

Yesterday he came here but today he gets permission not to come'

The phenomenon of code mixing in the utterances above has helped Balinese people to solve their problem in communication with people they have to respect. The use of one or more Balinese high level words into Indonesian discourses has been considered to have respectful meaning. The hearers know that although the speakers can't speak Balinese, they keep trying to show their respect to the hearers by method of code mixing.

\section{Conclusion}

From the analysis carried out above, conclusions can be described as follow. Every language speaker wants to have good and harmonious communication when he gets in touch with others. It is necessary to create polite communication for harmonious and good communication. Speakers of languages having language levels do not have any problem to 
communicate politely as they can use the high level language in communication. Balinese as one of such languages has language level, such as low, middle (standard), and high level language. However, Balinese speakers, especially those who can't master and speak good Balinese they will have problem to speak polite Balinese. Based on the analysis, there are some strategies to communicate polite Balinese. The polite speaking strategies in Balinese include the use of indirect speech, the use of person and social deixis, and the use of certain lexicons.

\section{References}

[1] Kardana, I, N.: Morphosyntax of Balinese reciprocal constructions. Macrothink Int. J. Linguist. vol. 6 (3). pp. 169-180 (2014)

[2] Kusno, A and Rohman, A.: Bentuk-bentuk pelanggaran prinsip kesopanan dalam ceramah keagamaa. Lingua. vol. 11 (2). pp. 104-115 (2016)

[3] Dontcheva-Navratilova, O.: Politeness strategies in institutional speech acts. in Brno Seminar on Linguistic Studies in English (2005)

[4] Lorenzo-Dus, N and Bou-Franch, P.: Gender and politeness: Spanish and British undergraduates perceptions of appropriate requests. in Género. lenguaje y traducción. pp. 187-199 (2003)

[5] Senowarsito.: Politeness strategies in teacher-student interaction in an EFL classroom context. TEFLIN J. vol. 24 (1). pp. 82-96 (2013)

[6] Getkham, K.: Strategies used to politely present ideas in research writing. J. Educ. Pract. vol. 4 (9). pp. 128-133 (2013)

[7] Nishijima, Y.: Politeness in sign expressions: A comparison of English, German, and Japanese. Intercult. Commun. Stud. vol. 23 (2). pp. 110-123 (2014)

[8] Wibowo, S.: Efforts to maintain and develop Javaness language politeness. in International Seminar of Javanese Language (2005)

[9] Djadjasudarma, T, F.: Metode linguistik: Ancangan metode penelitian dan kajian. Bandung, Eresco (1993)

[10] Wijana, I, D, P.: Dasar-dasar pragmatik. Yogyakarta, Andi Yogyakarta (1996)

[11] Saeed, J, I.: Semantics. Malden, Blackwell Publishing Ltd (1997)

[12] Searle, J, R.: Expression and meaning: Studies in the theory of speech act. Cambridge, Cambridge University Press (1979)

[13] Leech, G, N.: Principles of pragmatic. London, Routledge (1983)

[14] Lindayana and Et.al.: Politeness of verbal and non-verbal directive speech acts in the ten grade students' leraning processof SMA Negeri 1 Mataram. RETORIKA J. Ilmu Bhs. vol. 4 (1) pp. 70-74 (2018)

[15] Syuhadak and Et.al.: Deiksis dalam bahasa Using di kabupaten Banyuwangi. Lingua. vol. 12 (1). pp. 37-48 (2017) 